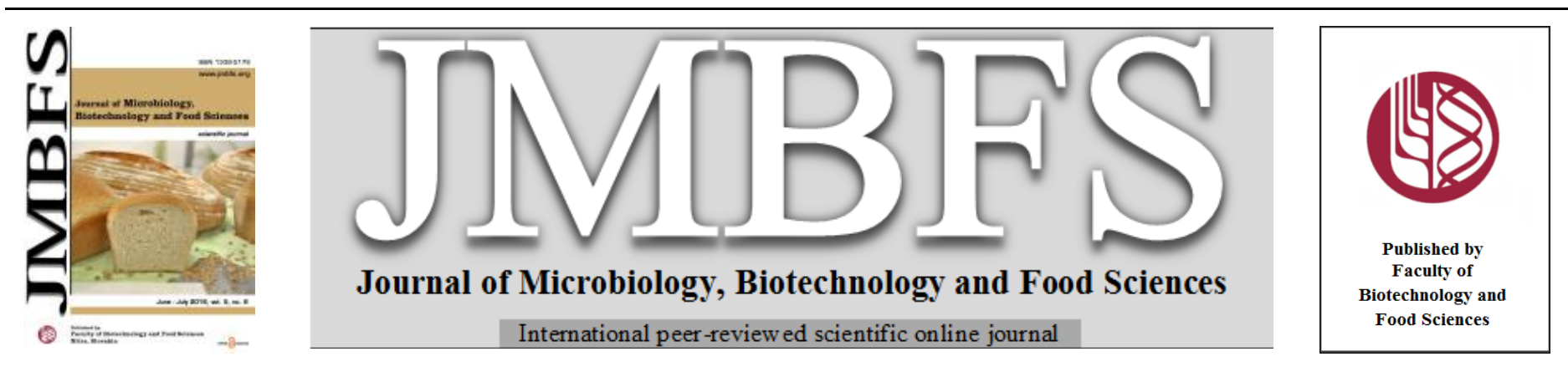

\title{
IDIOSYNCRASY OF LOCAL FUNGAL ISOLATE HYPOCREA RUFA STRAIN P2: PLANT GROWTH PROMOTION AND MYCOPARASITISM
}

\author{
Parth Thakor ${ }^{1,2}$, Dweipayan Goswami ${ }^{3}$, Janki Thakker $^{4}$ and Pinakin Dhandhukia ${ }^{1 *}$
}

Address(es): Dr. Pinakin Dhandhukia

Department of Integrated Biotechnology, Ashok and Rita Patel Institute of Integrated Study and Research in Biotechnology and Allied Sciences, ADIT Campus, New Vidyangar-388121, Anand (Gujarat), India; +91-2692-229189 Fax: +91-2692-229189.

${ }^{1}$ Department of Integrated Biotechnology, Ashok and Rita Patel Institute of Integrated Study and Research in Biotechnology and Allied Sciences, ADIT Campus, New Vidyangar-388121, Anand (Gujarat), India; +91-2692-229189 Fax: +91-2692-229189.

${ }^{2}$ Department of Biosciences, Sardar Patel University, VallabhVidyanagar-388120.

${ }^{3}$ Department of Biotechnology, St. Xavier's college (Autonomous), Ahmedabad-380009, Gujarat, India.

${ }^{4}$ Department of Biotechnology, P.D. Patel Institute of Applied Sciences, Charotar University of Science and Technology, CHARUSAT Campus, Changa-388421, Anand (Gujarat), India.

*Corresponding author: pinakin.dhandhukia@gmail.com

doi: 10.15414/jmbfs.2016.5.6.593-598

\section{ARTICLE INFO}

Received 16. 12.2014

Revised 11.2. 2016

Accepted 23. 2. 2016

Published 1. 6. 2016

Regular article open $\odot$ access

\begin{abstract}
Trichoderma viride an anamorph of Hypocrea rufa, is a known bio-control agent against various fungal phytopathogens. In the present study, H. rufa strain P2 was tested for plant growth promoting (PGP) traits and antifungal activity against Fusarium oxysporum, Alternaria alternata, Aspergillus niger, Sclerotium rolfsii. In-vitro assessment of $H$. rufa strain P2 showed maximum IAA production of $68 \mu \mathrm{g} \mathrm{ml}^{-1}$, solubilised tri-calcium phosphate up to $72 \mu \mathrm{g} \mathrm{ml}^{-1}$ and showed production of chitinase enzyme $120 \mathrm{U} \mathrm{ml}^{-1}$. In order to determine in-vivo plant growth promotion, talc based formulation of $H$. rufa strain $\mathrm{P} 2$ was prepared and tested on Arachis hypogaea $\mathrm{L}$. using seed and soil application. After 15 days, treated plants showed six-fold increases in the fresh and dry root mass whereas, fresh and dry shoot mass was increased up to two folds. The result indicates the local isolate $H$. rufa strain P2 can be categorized as phyto-friendly fungi which can be used as both, bio-control agent as well as phyto-augmenting bio-fertilizer.
\end{abstract}

Keywords: Hypocrea rufa strain P2; Plant Growth Promoting Fungi (PGPF); Chitinase; talc based bio-formulation; Peanut (Arachis hypogaea L.)

\section{INTRODUCTION}

Rhizospheric fungi have the ability to stimulate plant growth are designated as 'Plant Growth Promoting Fungi' (PGPF) (Hyakumachi, 1994). PGPF is nonpathogenic soil inhabiting saprophytes, which have been reported for growth promotion in several crop plants and providing protection against diseases (Shivanna et al., 1996). Such PGPF belongs to various genera, including Penicillium, Trichoderma, Fusarium, and Phoma. Few species of PGPF have been reported to trigger systemic resistance against numerous phytopathogens (Shoresh et al., 2005). Hypocrea rufa is a common inhabitant of the rhizosphere and decisively recognized as a bio-control agent of soil-borne plant pathogens (Harman et al., 2004). A praiseworthy amount of research has been focused on the mycoparasitic nature of $H$. rufa and its contribution in plant growth promotion. Antibiosis, competition, and mycoparasitism are the different mechanisms by which $H$. rufa controls plant-pathogenic fungi (John et al., 2010). The complex process of mycoparasitism requires the production of plenty of cell-wall-degrading enzymes, such as chitinases, cellulases, polysaccharide lyases, proteases, and lipases, which digest the fungal cell wall (Witkowska and Maj, 2002; Gruber and Seidl-Seiboth, 2012; Phitsuwan et al., 2013).

The mechanism of PGPF mediated plant growth promotion involves the production of various phytohormones like indole acetic acid (IAA) (ContrerasCornejo et al., 2009), gibberellic acid and cytokinins (Salas-Marina et al., 2011). Moreover, plant growth promotion is also supported by the production of siderophore, mobilization of insoluble phosphate, induction of different plant pathogen defense-related enzymes (i.e. $\beta-1,3$ glucanase, chitinases). Production of such enzymes contributed to their biocontrol characteristics (Dey et al., 2004; Chandler et al., 2008). Reduction in severity of plant diseases by application of H. rufa under field conditions was also reported by Hermosa et al. (2012). Field trials using talc-based bio-formulation of $H$. rufa was reported in India for the management of several soil-borne diseases applied through seed treatment and soil application (Jeyarajan, 2006; Mukherjee et al., 2012).
Groundnut (Arachis hypogaea L.) is an important oilseed crop in India. Gujarat is the principal producer state of groundnut in the country. The area and production of groundnut in the state found about 30.9 per cent and 37.1 per cent respectively in India (Swain 2013). The yield of groundnut is dropping by 25 per cent from $1,170 \mathrm{~kg}$ per hectare to $1,560 \mathrm{~kg}$ per hectare in Gujarat (SEA crop survey 2014). Various biotic and abiotic factors are responsible for this loss. There is 28 to 50 $\%$ of mortality observed due to plant fungal pathogen (Ghewande et al., 2002). Various remedies like crop rotations, use of recommended chemical fungicide etc. are available to effectively control fungal disease. However, these types of strategies affect human health, environmental pollution, development of pathogen resistance to fungicide and the production cost (Patel et al., 2015b). Apart from all these strategies, an unconventional approach is by inoculating crop seeds and seedlings with plant growth promoting organisms (Patel et al., 2015a).

In spite of the well-documented history of $H$. rufa as a biofertilizer and biocontrol agent, very few researchers have aimed to test multiple traits from a single isolate simultaneously. Therefore, in the present study, multiple traits of PGPF were accessed in a local isolate $H$. rufa strain P2 along with its antagonistic activity against several fungal pathogens. In-vivo plant growth promoting the activity of H. rufa strain P2 was determined using Arachis hypogaea L. as a test plant.

\section{MATERIALS AND METHODS}

\section{Sample collection and Isolation}

Farm soil sample was collected randomly at $15 \mathrm{~cm}$ soil depth using a cylindrical tube, from Anand, Gujarat $\left(22^{\circ} 53^{\prime} \mathrm{N}, 72^{\circ} 96^{\prime} \mathrm{E}\right)$. One gram of soil was suspended in $9 \mathrm{ml}$ of sterile distilled water. The serial aliquot of $0.1 \mathrm{ml}$ was plated on selective medium, Rose Bengal agar with pentachloronitrobenzene (PCNB), and incubated at $28 \pm 2^{\circ} \mathrm{C}$ for 5-7 days. Isolate has shown green conidia was used further for experiments and identified using $18 \mathrm{~S}$ rRNA gene sequencing. Pure culture was maintained and stored at $4^{\circ} \mathrm{C}$ on PDA. 


\section{Identification of isolate and morphological characterization}

Isolate was grown for 5 days at $28 \pm 2^{\circ} \mathrm{C}$ in $100 \mathrm{ml}$ of potato dextrose broth. Mycelia were collected by centrifugation. Fungal DNA extraction was done using GeNei ${ }^{\mathrm{TM}}$ Fungal Genomic DNA Extraction kit (Bangalore Genei, India) PCR amplification of $18 \mathrm{~S}$ rRNA gene from the purified genomic DNA was carried out using the following primers (forward primer 5'GGAAGTAAAAGTCGTAACAAGG-3' and reverse primer 5' TCCTCCGCTTATTGATATGC-3'). Thermal cycler conditions involved an initial denaturation step at $95^{\circ} \mathrm{C}$ for $5 \mathrm{~min}$, followed by 30 cycles of $94^{\circ} \mathrm{C}$ for 1 $\min , 55^{\circ} \mathrm{C}$ for $1 \mathrm{~min}$ and $72^{\circ} \mathrm{C}$ for $1 \mathrm{~min}$, and a final extension at $72^{\circ} \mathrm{C}$ for $1 \mathrm{~min}$ followed by holding at $4^{\circ} \mathrm{C}$. Amplified gene product was sequenced at $1^{\text {st }} \mathrm{BASE}$ (Agile Life Science Technologies India Pvt. Ltd.). The BLASTn search program (http://www.ncbi.nlm.nih.gov) was used to look for nucleotide sequence homology. The gene sequence was submitted to GenBank under accession number KC351188. The similar sequences from the database obtained were then aligned by ClustalW using MEGA 4.0 software (Tamura et al., 2007) and a neighbor-joining (NJ) tree with bootstrap value 500 was generated. Morphological characteristics of the isolate were studied. Arrangements of conidia were visualized under a light compound microscope.

\section{Selection of medium showing optimum growth of the fungal isolate}

Sterile $100 \mathrm{ml}$ Potato Dextrose Broth (PDB), Czapek Dox Broth (CDB) and Malt Extract Broth (MEB) were prepared in $250 \mathrm{ml}$ flasks. All flasks were inoculated with $10 \mathrm{~mm}$ plug of $H$. rufa strain P2. All flasks were incubated at $28 \pm 2^{\circ} \mathrm{C}$ at 130 $\mathrm{rpm}$. After completion of 3 and 6 days, the content of the flasks was filtered using pre-weighed Whatman filter paper No.1 and dried in hot air oven at $95^{\circ} \mathrm{C}$ until three constant weights of mycelia were obtained.

\section{Assessment of plant growth promoting (PGP) traits}

IAA production by isolate was determined using a method of Bano and Musarrat (2003). The quantitative estimation of a tri-calcium phosphate solubilisation by the isolate in the liquid Pikovskaya's medium was estimated using a method described by Pikovskayas (1948). The pattern of change in the $\mathrm{pH}$ of the medium was recorded along with the tri-calcium phosphate solubilization using a $\mathrm{pH}$ meter. The concentration of the soluble phosphate was estimated from the supernatant using stannous chloride method after 13 days of incubation given by Usharani and Lakshmanaperumalsamy (2010). For ammonia production, the isolate was inoculated in peptone water and incubated for five days at $28 \pm 2{ }^{\circ} \mathrm{C}$. Biomass was separated through filtration and supernatant was used for estimation of ammonia production by the method given by Demutskaya and Kalinichenko (2010). The concentration of ammonia was estimated against a standard curve of ammonium sulfate in the range of 0.1-1 $\mu \mathrm{mol} \mathrm{ml}{ }^{-1}$. For the qualitative estimation of $\mathrm{HCN}$ production, Picrate assay was performed (Kang et al., 2010).

\section{Biocontrol activity}

The antagonistic capability of isolate P2 was assessed against prominent phytopathogens including Fusarium oxysporum (MTCC 3930), Alternaria alternata (MTCC 6572), Aspergillus niger (MTCC 2196), Sclerotium rolfsii (MTCC 6052) using dual culture technique (Patel et al., 2015b) with sligh modification. Briefly, $10 \mathrm{~mm}$ diameter plug of the mycelial disc of a pathogenic fungus was taken from $6^{\text {th }}$-day old culture plates and put it on PDA plates at one end in an inverted position and simultaneously, the other end was inoculated with the isolate. Plates were incubated at $28 \pm 2^{\circ} \mathrm{C}$ for five days. Inhibition percentage of a plant pathogen was calculated using formula $\%$ inhibition $=[(\mathrm{I} 1-\mathrm{I} 2) / \mathrm{I} 1] \mathrm{x}$ 100 . Where $\mathrm{I} 1=$ radial growth of isolate, $\mathrm{I} 2=$ radial growth of a pathogen in dua culture experiments (Radial growth of the fungal strains were measured in $\mathrm{mm}$ ).

\section{Establishment of association between biomass and Chitinase enzyme}

One agar plug of $10 \mathrm{~mm}$ size obtained from the four-day-old growth of $H$. rufa strain P2 was inoculated in $100 \mathrm{ml}$ of sterile malt extract broth in $250 \mathrm{ml}$ Erlenmeyer flasks and incubated at $28 \pm 2{ }^{\circ} \mathrm{C}$ at $130 \mathrm{rpm}$. On each successive day, dry mycelial weight was determined as described earlier. The filtrate was stored at $4^{\circ} \mathrm{C}$ till assay was performed. Chitinase assay was performed with the slight modification of the method given Lingappa and Lockwood (1962). Briefly, the assay mixture consists of $200 \mu \mathrm{l}$ broth, $300 \mu \mathrm{l}$ of $0.1 \mathrm{M}$ sodium acetate buffer (pH 5.0) and $500 \mu \mathrm{l}$ of $1.0 \%$ colloidal chitin and incubated at $37^{\circ} \mathrm{C}$ for 1 hour Then after $200 \mu \mathrm{l}$ of $1 \mathrm{~N} \mathrm{NaOH}$ were added to the each tube followed by centrifugation at $11000 \mathrm{rpm}$ for 10 minutes at $4^{\circ} \mathrm{C}$. $1 \mathrm{ml}$ of Schales' reagent $(0.5$ M Sodium Carbonate $+2.0 \mathrm{mM}$ Potassium Ferricyanide) was added to the $500 \mu \mathrm{l}$ supernatant was taken from each of tube followed by incubation in boiling water bath for 10-15 minutes. The absorbance was immediately measured at $420 \mathrm{~nm}$ using a spectrophotometer. The enzyme activity was calculated from a standard curve based on known concentrations of $\mathrm{N}$-acetyl- $\beta$-D-glucosamine. One unit of chitinase activity was defined as the amount of enzyme that liberated $1 \mu \mathrm{mol}$ of $\mathrm{N}$-acetyl glucose amine per hour.

\section{In vivo pot study}

The talc-based formulation of the isolated fungal strain was prepared (Soe and De Costa, 2012). Isolated strain was evaluated for its effects on the growth, yield and vegetative parameters of peanut (Arachis hypogaea L.). For ensuring complete sterilization, soil (medium black, pH 7.4) was sterilized at $121^{\circ} \mathrm{C}$ and $15 \mathrm{lbs}$ for $1 \mathrm{~h}$, thrice in autoclavable bags and $1 \mathrm{~kg}$ of soil was filled in a plastic pot of $16 \mathrm{~cm}$ diameter. Pots were watered at regular intervals. For bioformulation application, the pot study was divided into two groups; (A) seed coating and (B) soil application. Different vegetative parameters like shoot length, numbers of leaves, numbers of branches, tap root length, lateral root length, fresh and dry root mass, fresh and dry shoot mass were measured after 15 days after sowing (DAS). Pot without application of talc-based bio-formulation of the isolate was used as a control.

\section{Statistical analysis}

Analysis of Variance (ANOVA) was carried out using triplicate value to identify a significant difference in each vegetative parameter between treated (seed coating, soil application) and non-treated seeds (control). Mean values of triplicates were compared at significance levels of 5\%, 1\%, and 0.1\% LSD.

\section{RESULTS}

\section{Morphological characteristics of the isolate}

The isolate was grown on Rose Bengal agar amended with pentachloronitrobenzene (PCNB) as a green colony. One colony from the plate was transferred to PDA which was matured within 5 days at $28 \pm 2{ }^{\circ} \mathrm{C}$. Initially, isolate grew as a white color colony which turned into scattered blue-green or yellow-green patches after conidia formation. The colony was wooly and became compact; the patches were sometimes observed as concentric rings. The isolate was more readily visible on PDA and characterized rapidly by postulated branched conidiophores with lageniform phialides and green conidia born in slimy heads (Fig. 1) which were arranged repeatedly.
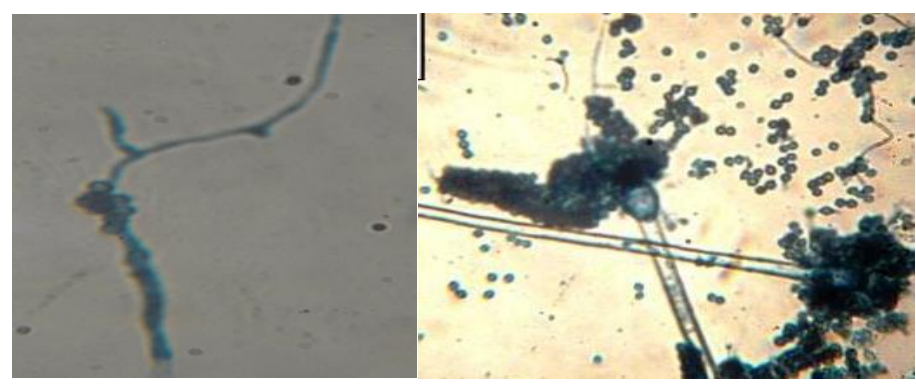

Figure 1 Microscopic observation of mycelia and conidiophores under compound microscope

\section{Identification of isolate}

Amplified 18S rRNA gene product was sequenced at $1^{\text {st }}$ BASE (Agile Life Science Technologies India Pvt. Ltd.). After performing BLASTn, 18S rRNA sequences of organisms showing maximum similarity were aligned by using ClustalW and an NJ tree was developed using software MEGA 4.0 with Bootstrap values based on 500 replications, which are listed as percentages at the branching points (Fig. 2). Gene sequence has been deposited in the GenBank nucleotide sequence database under the accession number KC351188. 18S rRNA sequence of $H$. rufa strain P2 showed maximum similarity with $H$. rufa strain W63 (JN935058).

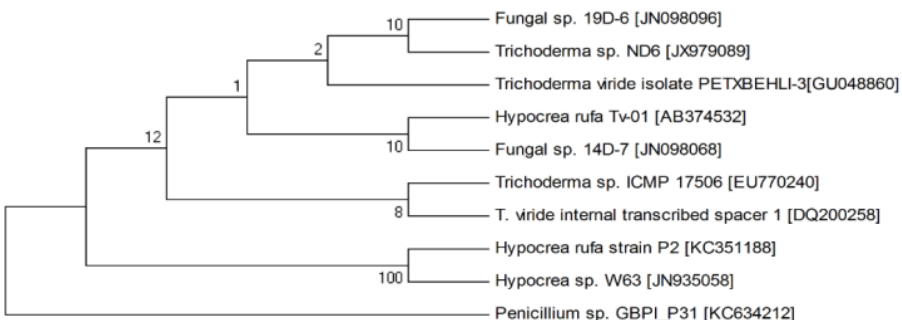

Figure 2 Phylogenetic analysis based on 18S rRNA gene sequences available from European Molecular Biology Laboratory (EMBL) library constructed after multiple alignments of data by ClustalW. Distances and clustering with the neighbor-joining method were performed using MEGA 4.0 software package. 
Bootstrap values based on 500 replications listed as per percentages at the branching points

\section{Selection of the medium for the growth of organism}

Liquid mediums viz., MEB, PDB, and CDB, were used to compare the growth of isolate which was measured as dry mycelia weight (DMW). Out of these three media, MEB best supported the growth of isolate. More than four-fold increase in DMW was obtained in MEB when compared to CDB and PDB on the third day. Even on the sixth day, DMW was more than two-fold higher in MEB (Fig. 3).

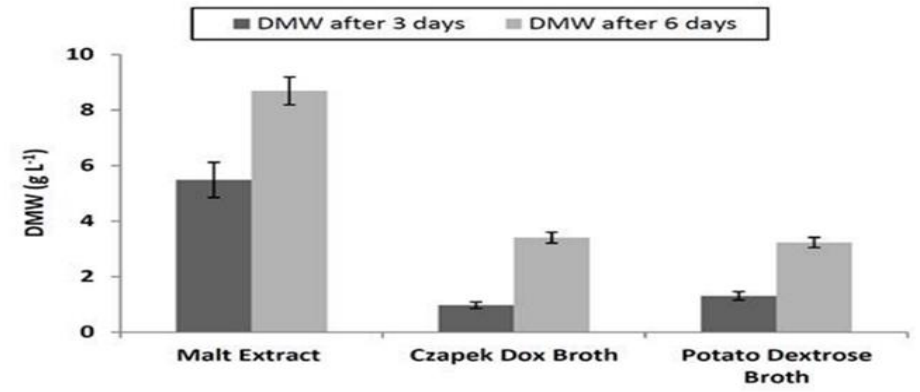

Figure 3 Comparative analysis of Dry Mycelial Weight (DMW) using fluid mediums for the growth of $H$. rufa strain $\mathrm{P} 2$ at $3^{\text {rd }}$ and $6^{\text {th }}$ day

\section{Plant growth promoting traits}

The isolate was assessed for IAA production. $H$. rufa strain P2 in PDB medium showed the maximum of $72 \mu \mathrm{g} \mathrm{ml}^{-1}$ production of IAA after $120 \mathrm{~h}$ (Fig. 4). To verify the relation between IAA production by the strain and the concentration of its precursor L-tryptophan, increasing the amount of this amino acid was added to the culture medium and production of IAA was estimated. The concurrent increase in IAA production was observed with increasing amount of LTryptophan supplementation (Fig. 4).

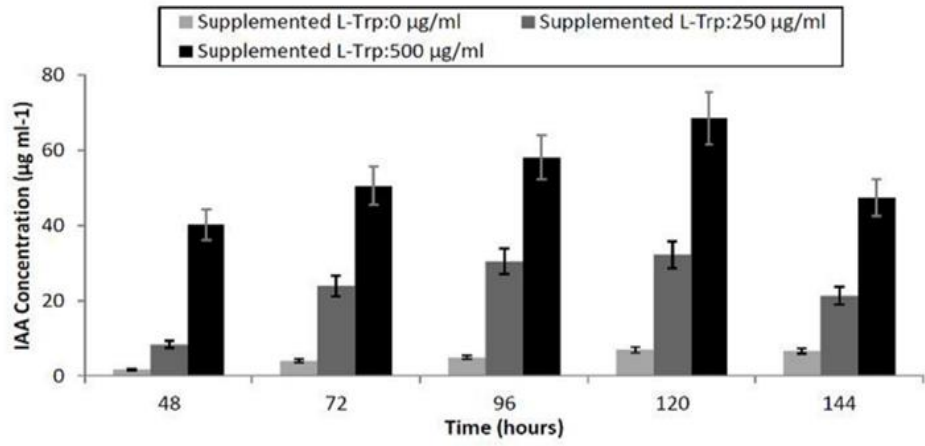

Figure 4 Correlation between IAA production and supplemented L-Tryptophan in the PDB medium at different time intervals by $H$. rufa strain P2

Isolate has shown the promising result for solubilisation of tri-calcium phosphate (Fig. 5). Isolate is capable of solubilizing inorganic phosphate by the production of organic acid. Isolate was capable of solubilizing maximum of $72 \mu \mathrm{g} \mathrm{ml}^{-1}$ of tricalcium phosphate after 11 days of incubation in the liquid Pikovskaya's broth Initial $\mathrm{pH}$ of the Pikovskaya's medium prior to inoculation of the isolate was adjusted to 7.0 but the $\mathrm{pH}$ was decreased to 4.21 after 11 days of incubation indicating the production of organic acids. Isolate produced $2.35 \mu \mathrm{mol} \mathrm{ml}{ }^{-1}$ of ammonia in peptone water. However, HCN production was not detected.

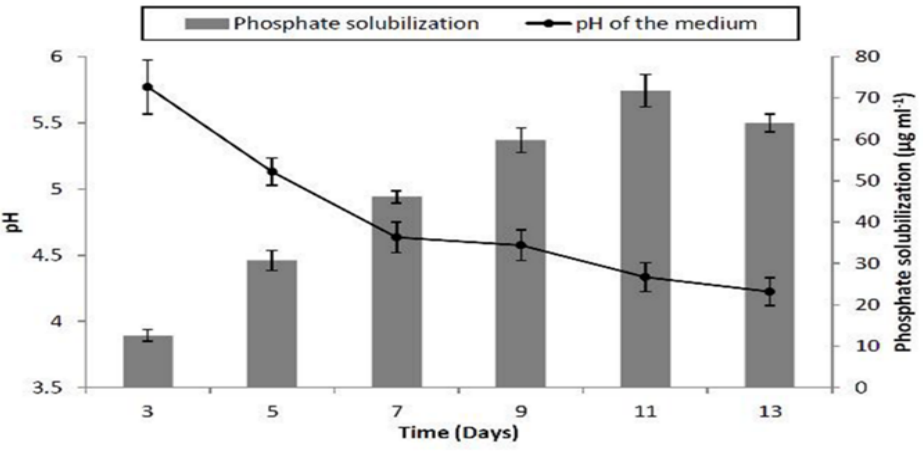

Figure 5 Correlation between tri-Calcium Phosphate solubilization and change in $\mathrm{pH}$ at different time intervals from $H$. rufa strain P2 in Pikovskaya's broth

\section{Biocontrol activity}

Isolate successfully inhibit potent plant pathogenic fungi viz., $F$. oxysporum (MTCC 3930), A. alternata (MTCC 6572), A. niger (MTCC 2196), S. rolfsi (MTCC 6052) under in-vitro conditions. The percentage inhibition varied with the pathogen. The percentage of inhibition was $57.6 \%, 48 \%, 34 \%$, and $30 \%$ respectively for $F$. oxysporum (MTCC 3930), A. alternata (MTCC 6572), A niger (MTCC 2196), S. rolfsii (MTCC 6052) (Fig. 6e).
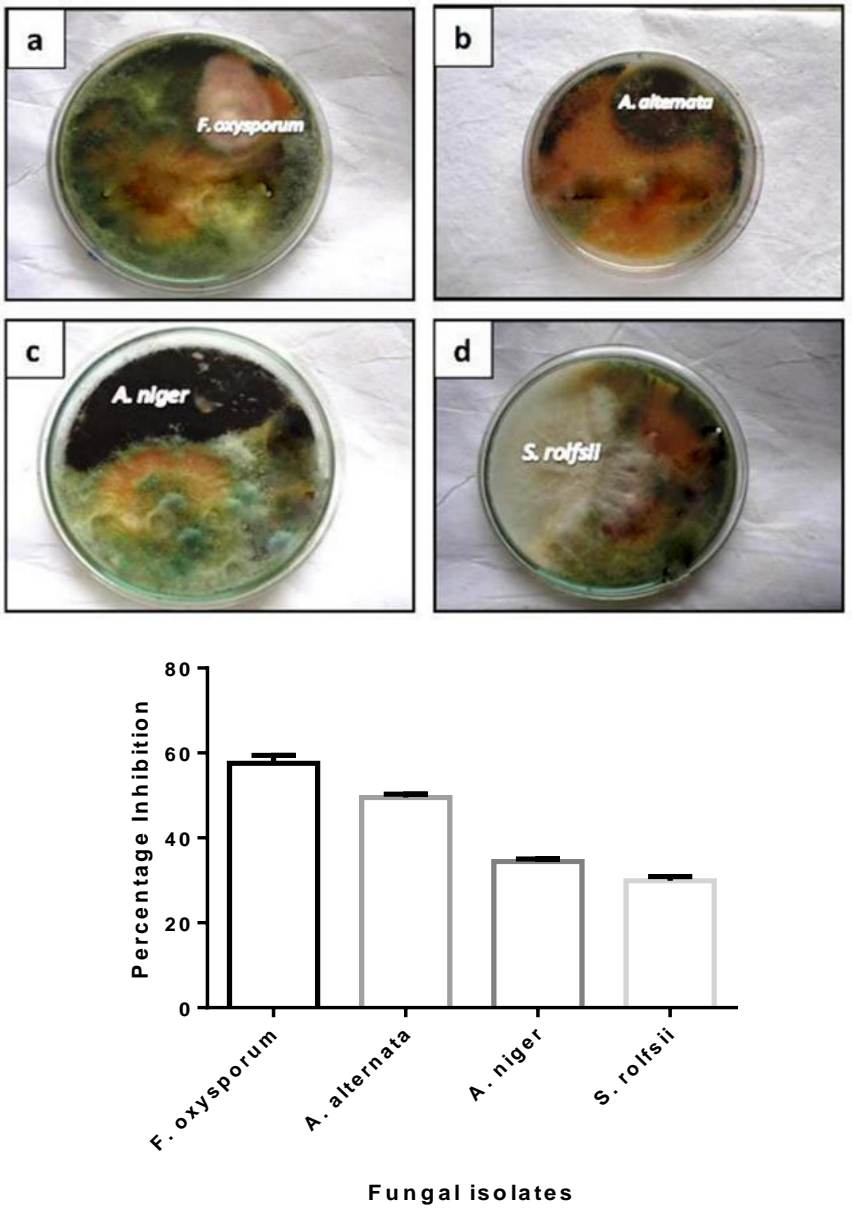

Figure 6 In-vitro Antagonistic activity of $H$. rufa strain P2 against (a) Fusarium oxysporum (b) Alternaria alternata (c) Aspergillus niger (d) Sclerotium rolfsii (e) antagonistic activity of the isolate as bar diagram

\section{Establishment of association between biomass and Chitinase enzyme activity}

In this study, biomass increased up to the $6^{\text {th }}$ day and later gradually depleted till the $13^{\text {th }}$ day. Moreover, isolate showed characteristic antagonistic activity. Antagonistic activity is a key attribute for the bio-control agent. Chitinase is one of the important enzyme responsible for the inhibition of fungal pathogens. The cell wall of fungi made up of chitin. Therefore, corresponding changes in chitinase activity were estimated and related to the growth of the fungi to determine the association between a decrease in biomass and chitinase activity. In the present study, results showed a clear association between biomass and chitinase activity. There was an increase in biomass up to the $6^{\text {th }}$ day when the chitinase activity was at the basal level, later on, chitinase activity rapidly increased with the consequent depletion of the biomass due to its own degradation by the enzyme. A similar trend was observed on day $11^{\text {th }}$ (Fig. 7) 


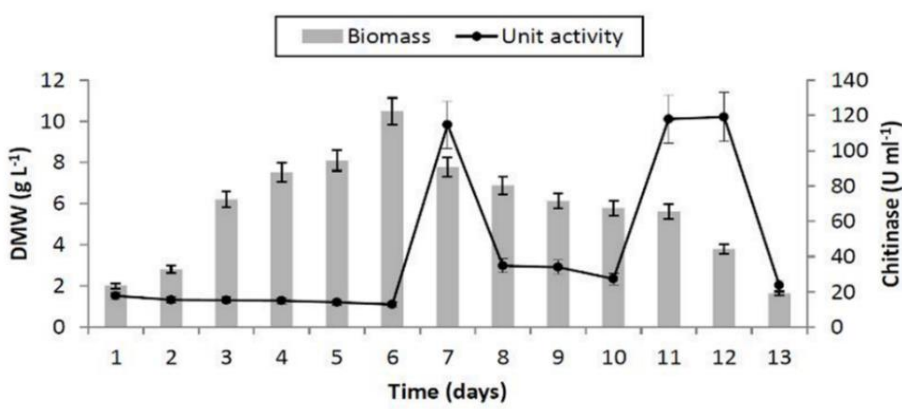

Figure 7 Association between biomass production and activity of chitinase by $H$. rufa strain $\mathrm{P} 2$

\section{In vivo pot Study}

Pot trials were carried out using Arachis hypogaea L. as a test plant. A significant difference in vegetative parameters of the control plant and treated plants (i.e. Seed coating application and soil application of talc based formulation of isolate) was observed. Seed coat and soil application of talc based formulation of isolate resulted in up to 2 fold increase in the numbers of leaves (Table 1). Similar growth promotion was also observed in the numbers of branches ( 2 folds) for seed application and (1.8 fold) for soil application treatment where the $\mathrm{P}$ value was found to be less than 0.01. Furthermore, significant growth promotion in shoot length (117\% for seed application and $135 \%$ for soil application) was observed for test plantlets as compared to control. Moreover, 1.25 fold and 3 fold increment in lateral roots of test plant were observed for seed and soil application treatment respectively (Fig. 8).
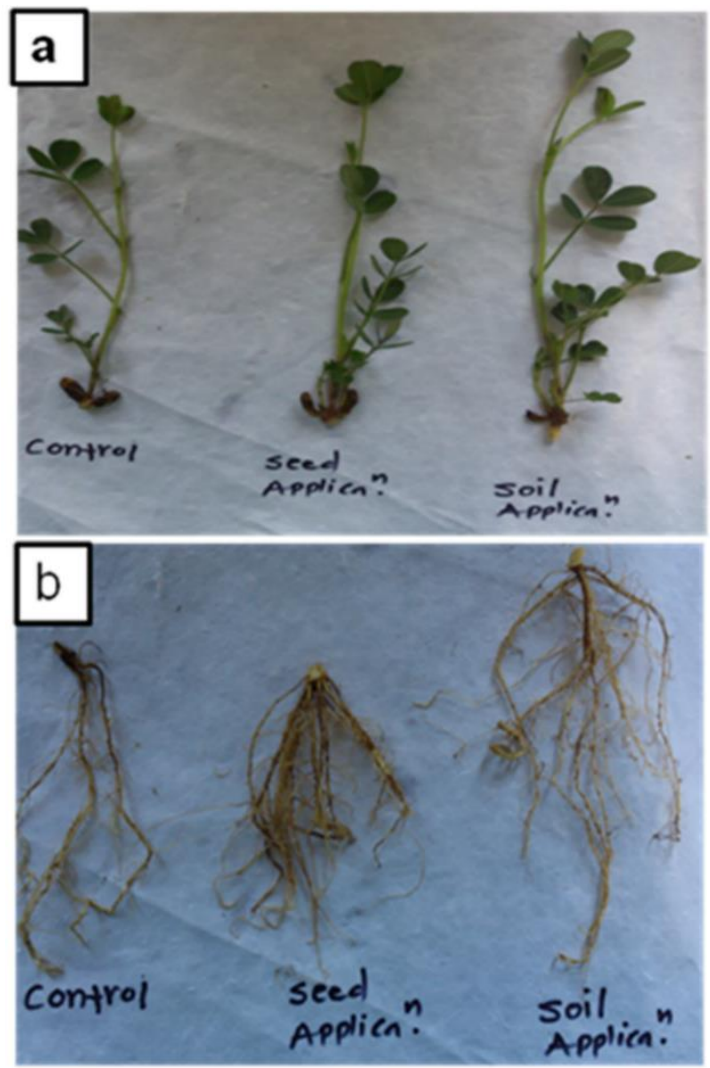

Figure 8 Difference in (a) the size of seedling and (b) in root growth between non-treated controls with $H$. rufa strain P2 treated soil and seeds.

Increased fresh root mass $(1.68$ fold in seed application and 2 fold in soil application) along with significant increment in dry root mass (3.78 and 6 fold in seed and soil application respectively) were achieved for treated plantlets. Increase in shoot fresh and dry mass was observed for both the treatments in test plants (Table 1)

Table 1 Effect of talc-based bio-formulation of $H$. rufa strain P2 on the germination of Peanut after 15 DAS (Days after sowing) in pots with two ways of application

Values are the mean of triplicates with standard deviation.

\begin{tabular}{llllll}
\hline Vegetative parameters & Control & Seed Application & P-value & Soil Application \\
\hline Numbers of leaves & $20.00 \pm 8$ & $41.3333 \pm 6.1101^{*}$ & 0.02137 & $36.00 \pm 4^{*}$ & P-value \\
Numbers of branches & $5.00 \pm 2$ & $10.3333 \pm 1.5275^{*}$ & 0.02138 & $9.00 \pm 1^{*}$ & 0.036278 \\
Shoot length (cm) & $17.00 \pm 2.6457$ & $20.100 \pm 2.0074$ & 0.18125 & $22.6666 \pm 2.5166$ \\
Numbers of tap root & $2.33 \pm 0.5773$ & $9.333 \pm 1.5275^{* *}$ & 0.00176 & $1.00 \pm 0.000^{*}$ \\
Tap root length (cm) & $14.83 \pm 2.2546$ & $10.933 \pm 1.1015$ & 0.05455 & $14.7667 \pm 2.1126$ \\
Lateral root length (cm) & $3.53 \pm 0.5033$ & $4.600 \pm 1.0148$ & 0.17825 & $7.0666 \pm 2.3860$ \\
Fresh root mass (mg) & $650.00 \pm 150$ & $1092.000 \pm 228.0066^{*}$ & 0.04856 & $1337.6667 \pm 209.7721^{* *}$ & 0.01613 \\
Dry root Mass (mg) & $50.00 \pm 4$ & $189.000 \pm 28.5831^{* *}$ & 0.00113 & $303.33 \pm 47.2581^{* * *}$ \\
Fresh shoot mass (mg) & $1238.00 \pm 88.42$ & $1946.667 \pm 261.0715^{*}$ & 0.01122 & $2441.00 \pm 206.64 * * *$ & 0.00076 \\
Dry shoot mass (mg) & $240.00 \pm 15$ & $330.000 \pm 26.4575^{* *}$ & 0.00686 & $453.33 \pm 15.2752^{* * *}$ & 0.00075 \\
\hline
\end{tabular}

* (P value between 0.05 to 0.01$)$ Significant at $5 \%$ compared to control (ANOVA)

** (P value between 0.01 to 0.001 ) Significant at $1 \%$ compared to control (ANOVA)

*** (P value less than 0.0001 ) Significant at $0.1 \%$ compared to control (ANOVA)

\section{DISCUSSION}

Several species of Trichoderma are widely known for their ability to be used as a bio-fertilizer and as a bio-control agent. Efforts are being made to commercialize isolates belonging to this genus. Therefore in the present study, the role of $H$. rufa strain $\mathrm{P} 2$ as biofertilizer and as an antagonist to several funga phytopathogens was determined. Also, for commercialization, it is a very essential to know the optimum growth medium which can support maximum biomass production. Therefore, we also studied the biomass of the fungus produced in several commercially available growth media. MEB supported maximum growth of $H$. rufa strain P2. From the data obtained it is essential to understand the growth medium and the growth requirements of $H$. rufa strain P2. Malt extract contains components like glucose, oligomers, inorganic salts, protein Malt extract contains carbohydrates $91 \mathrm{~g}$ carbohydrates per $100 \mathrm{~g}$ (monosaccharides 10\%, disaccharides 42-43\%, oligosaccharides 38-39\%), inorganic salts $1.8 \%$, proteins $7.0 \%$, and vitamins $0.2 \%$ of the total composition This indicates that malt extract is not just providing carbon but also providing essential macro and micro nutrients. $H$. rufa strain P2 is saprophytic fungi that use a wide range of compounds as carbon and nitrogen sources. The carbon and energy requirements of $H$. rufa were similar to the Trichoderma sp. can be satisfied by monosaccharide and disaccharides (Papavizas, 1985). Amino acids, urea, nitrate, ammonium are most readily utilized sources of nitrogen in buffered media which support the vegetative growth of Trichoderma sp. (Danielson and Davey, 1973). Therefore, malt extract supported the higher growth of $H$. rufa strain $\mathrm{P} 2$ by producing up to $10 \mathrm{~g} \mathrm{~L}^{-1}$ of biomass.

$H$. rufa is categorized as L-Tryptophan dependent IAA producer dependent IAA producer (Gupta et al., 1999). So, here we proved this claim as we showed that $H$. rufa produces a higher concentration of IAA if the supplemented concentrations of L-tryptophan is also high. The isolate in this study showed several desirable features for PGPF and multiple action mechanisms, which 
suggest its potential for growth promotion in Arachis hypogaea L. One of these beneficial features can be observed as high levels of IAA produced after $120 \mathrm{~h}$ by fungus $H$. rufa strain $\mathrm{P} 2$, which are 12 fold high when compared to $T$. atroviride (Gravel et al., 2007; Mukherjee et al., 2012) and about two-fold higher than $T$. harzianum which produce IAA in range of 26-50 $\mu \mathrm{g} \mathrm{ml}^{-1}$ (Akladious and Abbas, 2012). In comparison with other fungi viz., Aspergillus CMU-LPS019, Fusarium CMU-BK001, CMU-JT007 and Paecilomyces CMU-CM009 which produced IAA in the range from 1.6-26.1 $\mu \mathrm{g} \mathrm{ml}^{-1}, H$. rufa strain $\mathrm{P} 2$ showed at least 2.5 fold higher production of IAA than these widely studied PGPF (Ruanpanun et al., 2010). Tryptophan is the most important precursor for IAA synthesis, although several tryptophan-independent pathways have been described. The synthesized IAA by PGPF mostly affects the root system, which depends upon the increasing the size and number of adventitious roots and roo ramifications, as a result root exudates are able to cover larger soil volume, which in the end providing a large amount of nutrients to the plant. However, the effect of IAA may vary according to the concentrations that are released into the root system and, depending on the plant variety.

The amount of $\mathrm{P}$ in the soil is $0.5 \%$ although only $0.1 \%$ is available to the plant The solubilisation of Tri-calcium-phosphate observed in the present study is related to decrease in $\mathrm{pH}$ of the culture medium through the production of organic acids by $H$. rufa strain $\mathrm{P} 2$ by the utilization of glucose as a carbon source Phosphate solubilizing fungi like Trichoderma sp. and Aspergillus sp. produces different kinds of organic acids viz., lactic, maleic, malic, acetic, tartaric, citric, fumaric and gluconic acid (Akintokun et al., 2007). Deficiency of $\mathrm{P}$ in turn severely restricts plant growth and yield. Trichoderma isolates solubilizing insoluble tricalcium phosphate (TCP) to various extents, T. viride TV $97(9.03 \mu \mathrm{g}$ $\left.\mathrm{ml}^{-1}\right), T$. virens PDBCTVs $12\left(9 \mu \mathrm{g} \mathrm{ml}^{-1}\right)$, and $T$. virens PDBCTVs $13(8.83 \mu \mathrm{g}$ $\mathrm{ml}^{-1}$ ) was able to solubilize only $70 \%$ of the amount solubilized by Bacillus megaterium (12.43 $\mathrm{g} \mathrm{m} \mathrm{m}^{-1}$ ) (Rudresh et al., 2005). Superior ability to improve phosphate availability by $H$. rufa strain $\mathrm{P} 2$ used in the present study was eviden through 1 to 6 fold more TCP solubilizing activity compared to previous reports. One of the important cause for the $H$. rufa strain P2 to be characterized as an antagonist to fungal phytopathogens is chitinase production which can easily degrade fungal cell wall. Trichoderma $\mathrm{sp}$. is an antagonistic fungus, which prevents the crops from diseases viz. root rots, wilts, brown rot, damping off, charcoal rot and other soil borne diseases in crops. Trichoderma sp. suppresses more than 60 species of pathogens including Pythium, Botrytis, Sclerotium, Fusarium, Ascochyta, and Alternaria on different plants like cucumbers, tomatoes, cabbages, peppers, peanut, coffee, sugarcane, apples, cauliflower, citrus, Chinese cabbage, sweet potatoes etc. Some of the fungal plant pathogens were inhibited by $H$. rufa strain P2 under present study is demonstrated (Fig. 6) The mycoparasitic activity of Trichoderma sp. against various phytopathogens and oomycetes are due to the lytic activity of cell wall-degrading enzymes (Howell, 2003). Enzymes such as chitinase, glucanase produced by the biocontrol agents are responsible for suppression of the plant pathogens. These enzymes functions by breaking down the polysaccharides, chitin, and $\beta$-glucans that impart rigidity of fungal cell walls resulted in the destroying cell wall integrity (Mukherjee et al., 2012).

One of the important cause of the $H$. rufa strain P2 to be characterized as an antagonistic to fungal phytopathogens is chitinase production which can easily degrade fungal cell wall. One of the interesting results suggesting a significant decrease in biomass on the $7^{\text {th }}$ day and then after an $11^{\text {th }}$ day in the growth medium could be due to autolysis of its own cell wall by own chitinase production (Fig. 7). H. rufa strain P2 is an anamorph of Trichoderma viride, so it behaves similarly to Trichoderma sp. Mechanism of parasitism by Trichoderma sp. is destructive, causing death of the host fungus attributed by the action of chitinase (Mukherjee et al., 2012). The process of autolysis allows the remodeling of its growth by utilizing its own nutrients released into the medium by the action of chitinase on its own cell wall. During this process, cell wall polysaccharides are apparently exposed and consequently degraded. It is also possible that during other processes in fungal colony development, e.g. hyphal branching and fusion, the localized accessibility and de-protection of chitin and another cell wall polysaccharides is a determining factor which plays important role in establishment of an association between chitinase, biomass production and shifting of biomass towards the production of chitinase (Gruber and SeidlSeiboth 2012). In the present study, a similar trend was observed. Exo-chitinase can control the growth of soil-borne pathogens through the degradation of cell wall made up of chitin (Solanki et al., 2011). Trichoderma sp. produces secondary metabolites including gliotoxin, gliovirin and paptaibols with known antimicrobial activities that have been shown to act synergistically with lytic enzymes to enhance the destruction of host cell walls (Djonovic et al., 2006; Mukherjee et al., 2012).

Biofertilizers are live formulations of agriculturally beneficial microorganisms. There are various ways of application i.e. seed, root or soil. Biofertilization improve nutrient status of the plant by various means including associative nitrogen fixation, phosphorus solubilization, siderophores production, altering the permeability and transforming nutrients in the rhizosphere resulting in the increasing their bio-availability. Biofertilizers can mobilize the nutrients availability to improve the soil health by their biological activity. Biofertilizer colonizes the rhizosphere and promotes plant growth through increased supply of primary nutrients for the host plant. (Goswami et al., 2014). Some of the biofertilizers act as a phytostimulator which has capacity of the production of various phytohormones like IAA, GA, Cytokines, and ethylene (Lugtenberg et al., 2002; Somers et al., 2004; Pindi et al., 2014). Biofertilizer plays a role like bio-pesticide by the way of production of antibiotics, siderophores, HCN (Vessey, 2003), while production of hydrolytic enzymes is also correlated with the mechanism of biofertilizer (Somers et al., 2004). Furthermore, the plant growth promotion by controlling phytopathogenic agents by means of acquired and induced systemic resistance (Chandler et al., 2008). In-vitro tests showed the presence of all these important traits which makes the local isolate P2 an efficient biocontrol as well as biofertilizer. Further, pot experiments confirmed the proposed scheme. H. rufa strain P2 used in the study showed 1.21-1.37 fold higher plant height after 14 DAS as compared to isolate studied by Nawangsih et al. (2012) for growth promotion and control the bacterial wilt disease in Peanut with PGPB biofertilizer (Fig. 8). Thus, from the entire study, it can be confirmed that $H$. rufa strain $\mathrm{P} 2$ had several potentials which promote its use as a biofertilizer with the trait of mycoparasitism.

\section{CONCLUSION}

Isolate $H$. rufa strain P2 exhibited potential plant growth-promoting traits in-vitro and could be a potential candidate for enhancing the growth of the plant and protect the plant from infection by pathogenic fungi. Seed application significantly improves vegetative parameters of Arachis hypogaea L. However, soil application showed clear edge with the more significant difference compared to control. Further evaluation in field condition is required concurrently with plant defense induction potential to evaluate candidature of isolate $H$. rufa strain $\mathrm{P} 2$ in field conditions.

Acknowledgments: Authors are thankful to Ashok and Rita Patel Institute of Integrated Study and Research in Biotechnology and Allied Sciences (ARIBAS) and Charotar University of Science and Technology (CHARUSAT) management for providing necessary facilities.

\section{REFERENCES}

AKINTOKUN, A., AKANDE, G., AKINTOKUN, P., POPOOLA, T. BABALOLA, A. 2007. Solubilization of insoluble phosphate by organic acid producing fungi isolated from Nigerian soil. International Journal of Soil Science, 2, 301-307. http://dx.doi.org/10.3923/ijss.2007.301.307

AKLADIOUS, S. A., ABBAS, S. M. 2012. Application of Trichoderma harziunum T22 as a biofertilizer supporting maize growth. African Journal of Biotechnology, 11(35), 8672-8683. http://dx.doi.org/10.5897/AJB11.4323

BANO, N., MUSARRAT, J. 2003. Characterization of a new Pseudomonas aeruginosa strain NJ-15 as a potential biocontrol agent. Current Microbiology, 46, 324-328. http://dx.doi.org/10.1007/s00284-002-3857-8

CHANDLER, D., DAVIDSON, G., GRANT, W., GREAVES, J., TATCHELL, M. 2008. Microbial biopesticides for integrated crop management: an assessment of environmental and regulatory sustainability. Trends in Food Science and Technology, 19, 275-283. http://dx.doi.org/10.1016/i.tifs.2007.12.009

CONTRERAS-CORNEJO, H., MACIAS-RODRIGUEZ, L., CORTES PENAGOS, C., LOPEZ-BUCIO, J. 2009. Trichoderma virens, a Plant Beneficial Fungus, Enhances Biomass Production and Promotes Lateral Root Growth through an Auxin-Dependent Mechanism in Arabidopsis. Plant Physiology, 149 1579 -1592. http://dx.doi.org/10.1104/pp.108.130369

DANIELSON, R. M., DAVEY, C. B. 1973. Effects of nutrients and acidity on phialospore germination of Trichoderma in-vitro. Soil Biology and Biochemistry, 5, 517-524. http://dx.doi.org/10.1016/0038-0717(73)90041-2

DEMUTSKAYA, L. N., KALINICHENKO, I. E. 2010. Photometric determination of ammonium nitrogen with the Nessler reagent in drinking water after its chlorination. Journal of Water Chemistry and Technology, 32(2), 90-94 http://dx.doi.org/10.3103/S1063455X10020049

DEY, R., PAL, K., BHATT, D., CHAUHAN, S. 2004. Growth promotion and yield enhancement of peanut (Arachis hypogaea L.) by application of plant growth-promoting rhizobacteria. Microbiological Research, 159, 371-394 http://dx.doi.org/10.1016/j.micres.2004.08.004

DJONOVIC, S., POZO, M., KENERLEY, C. 2006. Tvbgn3, a ß1, 6-Glucanase from the biocontrol fungus Trichoderma virens, is involved in Mycoparasitism and control of Pythium ultimum. Applied and Environmental Microbiology, 72(12), 7661-7670. http://dx.doi.org/10.1128/AEM.01607-06

GOSWAMI, D., DHANDHUKIA, P., PATEL, P., THAKKER, J. 2014 Screening of PGPR from saline desert of Kutch: Growth promotion in Arachis hypogea by Bacillus licheniformis A2. Microbiological Research, 169(1), 66-75 http://dx.doi.org/10.1016/j.micres.2013.07.004

GRAVEL, V., ANTOUN, H., TWEDDELL, R. 2007. Growth stimulation and fruit yield improvement of greenhouse tomato plants by inoculation with Pseudomonas putida or Trichoderma atroviride: Possible role of indole acetic acid (IAA). Soil Biology and Biochemistry, 39, 1968-1977. http://dx.doi.org/10.1016/j.soilbio.2007.02.015 
GRUBER, S., SEIDL-SEIBOTH, V. 2012. Self versus non-self: fungal cell wall degradation in Trichoderma. Microbiology, 158, 26-34. http://dx.doi.org/10.1099/mic.0.052613-0

GUPTA V. P., SHARMA D. D., REKHA M., CHANDRASHEKAR D. S. 1999 Integration of Trichoderma pseudokoningii with agrochemicals for disease management and plant development in mulberry. Arch Phytopathol Plant Protec, 32(6), 521-529. Doi:

$10.1080 / 03235409909383319$

HARMAN, G., HOWELL, C., VITERBO, A., CHET, I., LORITO, M. 2004 Trichoderma species-opportunistic, avirulent plant symbionts. Nature Reviews Microbiology, 2, 43-56. http://dx.doi.org/10.1038/nrmicro797

HERMOSA, R., VITERBO, A., CHET, I. MONTE, E. 2012. Trichoderma beneficial effects to plants and transgenic plants expressing Trichoderma genes. Microbiology, 158, 17-25. http://dx.doi.org/10.1099/mic.0.052274-0

HOWELL, C. R. 2003. Mechanisms employed by Trichoderma species in the biological control of plant diseases: The history and evolution of current concepts. Plant Disease, 87, 4-10. http://dx.doi.org/ 10.1094/PDIS.2003.87.1.4

HYAKUMACHI, M. 1994. Plant growth promoting fungi from turfgras rhizosphere with potential for disease suppression. Soil Microorganism, 44, 5368. Retrieved from http://ci.nii.ac.jp/naid/110009467810

JEYARAJAN, R. 2006. Prospects of indigenous mass production and formulation of Trichoderma. In: Rabindra RJ Ramanujam B (eds), Current Status of Biological Control of Plant diseases using antagonistic organisms in India. 7480.

JOHN, R., TYAGI, R., PREVOST, D., BRAR, S., POULEUR, S. SURAMPALLI, R. 2010. Mycoparasitic Trichoderma viride as a biocontrol agent against Fusarium oxysporum f. sp. adzuki and Pythium arrhenomanes and as a growth promoter of soybean. Crop Protection, 29, $1452-1459$. http://dx.doi.org/10.1016/j.cropro.2010.08.004

KANG, Y, CHENG, J, MEI, L., YIN, S. 2010. Screening and identification of plant growth promoting rhizobacteria. Acta microbiologica sinica, 50(7), 853861. Retrieved from http://www.ncbi.nlm.nih.gov/pubmed/20815230

LINGAPPA, Y., LOCKWOOD, J. L. (1962). Chitin media for selective isolation and culture of Actinomycetes. Phytopathol, 52, 37-323.

LUGTENBERG, B. J., CHIN-A-WOENG, T. F., BLOEMBERG, G. V. 2002 Microbe-plant interactions: principles and mechanisms. Antonie Van Leeuwenhoek, 81, 373-383. http://dx.doi.org/10.1023/A:1020596903142

MUKHERJEE, P. K., HORWITZ, B. A., KENERLEY, C. M. 2012. Secondary metabolism in Trichoderma - a genomic perspective. Microbiol, 158, 35-45. Doi 10.1099/mic.0.053629-0

NAWANGSIH, A. A., ADITYA, R., TJAHJONO, B., NEGISHI, H., SUYAMA, K. 2012. Bioefficacy and characterization of plant growth promoting bacteria to control the bacterial wilt disease of Peanut in Indonesia. J ISSAAS, 18(1), 185192

PAPAVIZAS, G. C. 1985. Trichoderma and Gliocladium: biology, ecology, and potential for biocontrol. Annual Review of Phytopathology, 23, 23-54. http://dx.doi.org/10.1146/annurev.py.23.090185.000323

PATEL, R. R., PATEL, D. D., THAKOR, P., PATEL, B., THAKKAR, V. R. 2015a. Alleviation of salt stress in germination of Vigna radiata L. by two halotolerant Bacilli sp. Isolated from saline habitats of Gujarat. Plant Growth Regul, 76, 51 -60. Doi: 10.1007/s10725-014-0008-8

PATEL, R. R., THAKKAR, V. R., SUBRAMANIAN, B. R. 2015b. A Pseudomonas guariconensis strain capable of promoting growth and controlling collar rot disease in Arachis hypogaea L. Plant Soil, 390, 369-381. Doi 10.1007/s11104-015-2436-2

PHITSUWAN, P., LAOHAKUNJIT, N., KERDCHOECHUEN, O., KYU, K., RATANAKHANOKCHAI, K. 2013. Present and potential applications of cellulases in agriculture, biotechnology and bioenergy. Folia Microbiol, 58, 163176. http://dx.doi.org/10.1007/s12223-012-0184-8

PIKOVSKAYAS, R. I. 1948. Mobilization of phosphorus in soil in connection with the vital activity of some microbial species. Mikrobiologiya, 17, 362-370.

PINDI, P. K., SULTANA, T., VOOTLA, P. K. 2014. Plant growth regulation of Bt-cotton through Bacillus species. 3 Biotech, 4, 305-315. Doi: 10.1007/s13205013-0154-0

RUANPANUN, P., TANGCHITSOMKID, N., HYDE, K., LUMYONG, S. 2010. Actinomycetes and fungi isolated from plant-parasitic nematode infested soils: screening of the effective biocontrol potential, indole-3-acetic acid and siderophore production. World Journal of Microbiology and Biotechnology, 26, 1569-1578. http://dx.doi.org/10.1007/s11274-010-0332-8

RUDRESH, D. L. SHIVAPRAKASH, M. K., PRASAD, R. D. 2005. Tricalcium phosphate solubilizing abilities of Trichoderma $s p$. in relation to $\mathrm{P}$ uptake and growth and yield parameters of chickpea (Cicer arietinum L.). Canadian Journal of Microbiology, 51, 217-222. http://dx.doi.org/10.1139/w04-127

SALAS-MARINA., MIGUEL, ANGEL., SILVA-FLORES, M. A., CERVANTES-BADILLO, M. G., ROSALES-SAAVEDRA, M. T., ISLASOSUNA, M. A., CASAS-FLORES, S. 2011. The plant growth-promoting fungus Aspergillus ustus promotes growth and induces resistance against different lifestyle pathogens in Arabidopsis thaliana. J Microbiol Biotechnol, 21(7), 686696. Doi: $10.4014 / \mathrm{jmb} .1101 .01012$
SEA crop survey reveals $26 \%$ decline in sowing and 25\% drop in yield. 2014. http://www.thehindubusinessline.com/economy/agri-business/gujarat-groundnutproduction-to-drop-44-sea/article6500922.ece

SHIVANNA, M. B., MEERA, M. S., HYAKUMACHI, M. 1996. Role of root colonization ability of plant growth promoting fungi in the suppression of take-all and common root rot of wheat. Crop Protection, 15, 497-504. http://dx.doi.org/10.1016/0261-2194(96)00004-X

SHORESH, M., YEDIDA, I., CHAT, I. 2005. Involvement of jasmonic acid/ethylene signaling pathway in the systemic resistance induced in cucumber by Trichoderma asperellum T203. Phytopathology, 95, 76-84. http://dx.doi.org/10.1094/PHYTO-95-0076

SOE, K. T., DE COSTA, D. M. 2012. Development of a spore based formulation of microbial pesticides for control of rice sheath blight. Biocontrol Science and Technology, 22(6), 633-657. http://dx.doi.org/10.1080/09583157.2012.676025

SOLANKI, M., SINGH, N., SINGH, R., SINGH, P., SRIVASTAVA, A., KUMAR, S., KASHYAP, P., ARORA, D. 2011. Plant defense activation and management of tomato root rot by a chitin-fortified Trichodermal Hypocrea formulation. Phytoparasitica, 39, 471-481. http://dx.doi.org/10.1007/s12600011-0188-y

SOMERS, E., VANDERLEYDEN, J., SRINIVASAN, M. 2004. Rhizosphere bacterial signalling: a love parade beneath our feet. Critical Reviews in Microbiology, 30, 205-240. http://dx.doi.org/10.1080/10408410490468786

Swain, M. 2013. Problems and Prospects of Oilseeds Production in Gujarat Special Reference to Groundnut. Report submitted to the Ministry of Agriculture, Government of India, New Delhi.

TAMURA, K., DUDLEY, J., NEI, M., KUMAR, S. 2007. MEGA4: Molecular Evolutionary Genetics Analysis (MEGA) software version 4.0. Molecular Biology and Evolution, 24, 1596-1599. http://dx.doi.org/ 10.1093/molbev/msm092

USHARANI, K., LAKSHMANAPERUMALSAMY, P. 2010. Bio-treatment of phosphate from synthetic wastewater using Pseudomonas sp YLW-7. Journal of Applied Science and Environment Management, 14(2), 75 - 80 http://dx.doi.org/10.4314/jasem.v14i2.57867

VESSEY, J. K. 2003. Plant growth promoting rhizobacteria as biofertilizers Plant and Soil, 255, 571-586. http://dx.doi.org/10.1023/A:1026037216893

WITKOWSKA. D., MAJ, A. 2002. Production of lytic enzymes by Trichoderma spp. And their effect on the growth of phytopathogenic fungi. Folia Microbiol, 47(3), 279-282. http://dx.doi.org/10.1007/BF02817652 